\title{
Financing higher education in sub-Saharan Africa: some reflections and implications for sustainable development
}

\author{
Moses Oketch ${ }^{1}$
}

Published online: 18 August 2016

(C) The Author(s) 2016. This article is published with open access at Springerlink.com

\begin{abstract}
The purpose of this article is to discuss how best to finance higher education in low-income countries of sub-Saharan Africa, drawing on benefits and drawbacks of the prevalent models of higher education finance, and lessons to be learned from countries which have seen greater expansion of their higher education systems in recent decades. Two main aspects are distinguished: first, a recognition of the powerful evidence that the general level of education in a country, its human capital, matters in determining a path to economic development; second, understanding that it does not help to produce large number of unemployed graduates whose only option due to absence of jobs is to engage in rent-seeking activities which in the end undermine both the essence of the human capital investment made, and job creation to be associated with human capital skills. Three areas are discussed, fully publicly financed "free" university education model; feasibility and lessons about fees; feasibility and lessons about loans. In addition, the paper makes suggestions on the measures to widen participation and promote equity and quality.
\end{abstract}

Keywords Higher education funding · Higher education access · Higher education equity Higher education and development · Sub-Saharan Africa

\section{Introduction}

Much literature confirms theoretically through human capital theory and empirically education's importance to economic growth (Becker 1993; Mankiw et al. 1992; Barro 2000; Hanushek and Woessmann 2008). Any nation that aspires to develop and improve the well-being of its citizens must therefore take its human capital investment seriously.

Moses Oketch

m.oketch@ucl.ac.uk

1 UCL Institute of Education, University College London, 20 Bedford Way, London WC1H 0AL, UK 
However, the mechanism for this effect of human capital on growth is diverse ranging from earnings, increased productivity, spill-over effects, to mention some of them (Keller 2006, p. 18; Oketch et al. 2014). Because earnings accrue to individuals who have participated in higher education and growth benefits entire society, this has generated much heat in the debates about who should bear the responsibility for the investment in higher education. These debates are common in high-income countries where endogenous growth models (Lucas 1988) continue to advocate for greater benefits from higher education generated by knowledge and innovation, but they have also generated heat in low-income countries which must invest in advanced human capital for their own development advancement sake (Oketch 2006) but also to function in a more globalised world. The case for development, notwithstanding, higher education all over the world, in one way of another, is paid for either by the taxpayer or individual students and their families. In some very few instances, prospective employers may offer funding; however, all over the world, higher education has become so expensive such that the debate today is much about which funding model or combination is economically feasible and sensible, practical and moral, within any given context. The recent riots by university students in South Africa over proposed fees increase of about ten per cent demonstrate the dilemma over the rising cost of higher education and who should pay for it.

The taxpayer-funded model seen as "free" can support effective but elite and small number of universities, especially in trends with a focus on fiscal rigour. Calls for widening participation are said to require greater diversification of funding or shifting costs to those demanding higher education (Barr 2004). There are some exceptions to this globally, especially in left-leaning Latin American countries such as Venezuela where there has been a rapid state-funded expansion, though possibly with compromises on the quality of provision. Thomas Muhr's contribution to this special issue addresses the cases of Venezuela and Brazil.

Authors such as McMahon agrees that in some cases, private funding is needed but a sensible balance is necessary and points out that “...if control of higher education is to be fully relinquished to private markets, then there needs to be analysis of the extent to which there may be market failure leading to distortions" (McMahon 2009, p. 2). But what do these debates on funding mean for higher education in sub-Saharan Africa countries which have seen a shift in their economic growth measured by GPD from decades of stagnation or negative growth to a much more positive outlook in recent years? For instance, in recent years, the region has seen growth rates of GDP growth above the global average and higher than advanced countries. This is unprecedented and has generated interest in the role of higher education and the concept of youth dividend in the region's development trajectory. If taken as important for the sustained development of Africa, how then should higher education be funded against competing demand for access and of resources for other development goals? This has generated interest in the funding models that can work, how and why?

This article serves to discuss the merits and challenges of the dominant models of higher education funding in sub-Saharan Africa, setting out in an intertwined manner the economic and moral considerations, and their implication for access and quality. The region remains one of the economically poorest in the world with low levels of participation in higher education; however, it has also recently seen widening participation in basic education associated with the Education for All framework and the MDGs which prioritised basic education and gender parity. This is putting pressure for access to both secondary and higher levels of education. The traditional taxpayer-funded university model has come under scrutiny and is considered both by governments and by liberal economists as 
unfeasible way for widening participation in this context. Furthermore, the original claim to universities as essential for training much needed civil servants for nation building has either been realised in some cases, or in others, is a less compelling argument. Therefore, a claim to the need to build civil service is no longer a clear-cut justification to have expanded "free" university education. Instead, governments are now calling for graduates who can be "job creators". The phrase frequently used is "university graduates who are entrepreneurs". However, there is less clarity on the philosophy of what this means for a young person who has just completed his or her degree and facing a lengthy period of unemployment. It is a signal that these governments in Africa want their universities but are unsure of what to do with their graduates or how to engage them. Graduates are left to their own devices to "create jobs".

Yet there is unprecedented demand, fuelled by youthful population in both rural and urban areas who aspire to higher education and see it as their only means towards social mobility, and a privileged urban minority who see university education as a normal passage to adulthood and the world of work. Both of these groups have demanded and defended "free" university education: the former on equity and widening participation grounds (aligned with social justice goals) and the latter on meritocracy and preservation of quality grounds. These positions are not unique to sub-Saharan Africa. Such debates on how to fund higher education and the role of loans and fees have occurred in the UK (see, e.g. Greenaway and Hayness 2003) where higher education participation in terms of gross enrolment ratio is about $60 \%$ (UIS 2014) in contrast to sub-Saharan Africa where it is just about $7 \%$. Since around mid-1990s, universities in several African countries have seen profound funding reorganisation which introduced elements of private funding or complete promotion of "entrepreneurial university". This reorganisation of funding and what it means is the focus of the remainder of this paper, along with debates around "free" and market funding models, and what these debates mean in Africa's context.

The rest of the paper is organised as follows. First, I present arguments justifying "free" university funding and relate these to Africa context. Second I discuss the actual funding models, notably fees and loans. Third, I reflect on expanding access and responding to demand, and finally I offer concluding discussion and thoughts on where higher education funding in sub-Saharan Africa is headed in the context of sustainable development aspirations.

\section{Justifying "free" university education}

\section{State versus the market}

The thrust of the arguments for or against either "free" or partial or full private market funding models is about whether costs outweigh benefits (Woodhall 2001). In the developed countries such as the UK, much of the funding recent debate in higher education has been both about value for money and about widening participation. This debate has been triggered by the severe cuts into university funding in the last few years, with many courses no longer receiving government subsidy and students required to make large contribution to their education by way of tuition fees of $£ 9000$ per year which the government contends is value for money and widens participation while critics disagree (Dearden et al. 2014). In the low-income countries, notably sub-Saharan Africa, it is far much more than value for money. There are both economic and moral arguments that have been made about whether 
widening participation through taxpayer funding model of "free" universities is justified when there is no fully established provision for universal basic education. The question often raised is why should the largely poor populations in sub-Saharan Africa be burdened with university costs which their children have little chance of ever attending because they do not have a chance of good basic education in the first place? The economic rate of return (Psacharopoulos 1994; Psacharopoulos and Patrinos 2004) which has raised a lot of heat in the debates about the role of higher education in development is often used as evidence to illustrate that private benefits from higher education outweigh societal benefits.

Those who have questioned the rate of return premise have noted that good higher education is part of good basic education (Teal 2011) meaning that it is never clear-cut to separate which part of the connection between education and economic development is due to basic education and which one is purely as a result of higher education investment. This implies that where schools are homogenised by pupils' socio-economic backgrounds, the schools that produce university "material" would be those which are mainly accessed by those from wealthy socio-economic backgrounds. Whatever the case, the rate of return argument won the case several years ago and has been cited in calls for greater diversification of funding and a shift in the university funding models away from purely taxpayerfunded model to those models whereby costs are pushed to wealthy students who are demanding higher education or where this is politically difficult there has been calls for greater sharing of higher education costs between taxpayers and the student and their families (Johnstone 1998; Oketch 2003). However, McMahon (2009, p. 2) has noted that the problem is that although families and students are conversant with the increases in earnings, a purely market benefit associated with acquiring higher education, they are often "only very vaguely aware of the value of non-market benefits beyond earnings that enhance the quality of life". As McMahon further points out, these private non-market benefits are hugely important as they are generated by a graduate's use of his or her human capital at home and in the community when they are not at work or sleeping, and the productivity of this time is enhanced greatly as a result of their higher education. In the end, there are benefits to the individual graduate's private well-being as well as benefits to others in the community and to future generations (McMahon 2009, p. 118/119). These private non-market benefits include: better own health, better child health, better spousal health, greater longevity, small family size, and increased happiness (also see McMahon and Oketch 2013, Table 2, p. 93). So the true benefits of higher education to the individual are narrowly conceived and understood if restricted to earnings only, and in the end funding policies guided purely by rate of return discourse does not produce higher education that embodies the framework of higher education's contribution to sustainable development. It perpetuates inequality in opportunity for access to and outcomes from higher education, especially in poor countries with high levels of corruption and inequality, even though it shifts costs away from governments to wealthy students and their families.

\section{Higher education is a basic right and should therefore be free}

As Barr (2004) notes, this is value judgement which "commands widespread agreement" (p. 266). Its foundation is equity (see e.g. McCowan (2012) discussion on "a universal right to higher education"). According to Barr, "equity objective is not free higher education, but a system in which no bright person is denied a place because he or she comes from a disadvantaged background" (p. 266). This is complex in low-income countries of sub-Saharan Africa where primary and secondary education already disadvantages majority, a point also highlighted by McCowan (2012) when he notes that "the task of ensuring equitable access is 
highly challenging in contemporary societies given the entrenched inequalities stemming from educational experiences prior to university entry" (p. 125). Those bright persons who would have demonstrated their potential but have no chance of demonstrating it at basic education level are in the majority. How then should a "rights approach" be implemented in such a context? The fundamental point that Barr raises is that when people talk about a free higher education, the consideration is to make "higher education free at the point of use". There are several arrangements that have been set out to make this possible and which I discuss in the sections that will follow later. The question is their feasibility and lessons learned from actual implementation in relation to access and quality.

\section{Other justifications}

Several other justifications for free or highly subsidised higher education appear in the literature. The idea of positive externalities (McMahon 2009; Keller 2006) is one of them. This is the notion that higher education benefits are captured by those who have not themselves attended higher education, but there are also several other private social benefits such as better own health which were ignored by rate of return estimates (McMahon and Oketch 2013). Critics of the externalities argument claim it does not suggest subsidising students at exactly the same rate (Rosen 1995; Fernandez and Rogerson 1995). Instead the positive externality argument supports subsidies that would encourage university education for bright individuals who left on their own may not invest the time needed in their studies in order to qualify for university education (Rozada and Menendez 2002).

Another argument that lends support for "free" or subsidised higher education relates to the "pathways" of higher education's impact to development framework (Oketch et al. 2014), which underpins higher education's integral contribution to an entire education system, and also the rule of law often so fundamental to proper functioning not only of society, but of its education as well. The rule of law is crucial because where it exists, the school system will tend to function well, with teachers who are accountable and schools that tend to be better managed. When higher education is neglected, this affects basic education. The manpower needed to strengthen basic education through teachers, and teacher training, are products of higher education. The lawyers needed for a functional judicial justice systems are products of higher education, and the process of democratisation has been empirically linked to higher education (Keller 2006). The policy and research needed to support the advancement and improvements in the provision and quality of basic education, and thus equity and social justice, are associated with skills acquired mainly through higher education. Therefore, neglecting higher education is perilous to basic education in any context and perilous to social justice in any context.

Nevertheless, the above are not the reasons why there is now resurgence in interest in higher education in sub-Saharan Africa. The role that the market can play or has already played is certainly one of them. Connected to this are several other driving forces such as unprecedented demand associated with prior high population growth rates; concerns over quality which would have later impact on labour market and productivity; acceptance about looking keenly at the alternative funding models that can support rapid demand or an attitude by governments that higher education can simply fund itself; and expansion in democratic space itself partly as a result of higher education, and consequently the election of political leaders who are not overly threatened or paranoid about a more educated population who can challenge or satirise their leadership excesses through the media. I should say here that this is not generalised: the flip side are leaders who have weakened the university system such that those acquiring degrees have limited critical intellectual capital 
to challenge political leadership. Flooding universities which produce graduates who are not readily employable may be seen as "development" by some political leaders.

\section{Opposition to the notion of a "free" university funding model}

Barr (2004) is among the staunch advocates of a system that is not entirely free. He says free higher education is bad for access. But he also has a moral conscience in his writing against free higher education when he notes that it is not only "immoral" to charge for education in contexts whereby. ... "people with the aptitude and desire are denied access to higher education because they cannot afford it; it is also immoral if underfunded earlier education means that they never even aspire to university" (Barr 2004, p. 266). Then he goes on to note that these arguments do not apply to suggestions of making food free so why should they apply to higher education? Here I ask how would Barr's argument of "free is bad for access" be reflected in the context of sub-Saharan Africa? The evidence seems to support his argument. There has been unprecedented expansion since the higher education sector was liberalised around mid-1990s. Over the last decade, in some countries, universities have emerged overnight, almost more than a dozen per year. Countries such as Kenya have seen mind-boggling growth from a handful of universities about a decade ago to around 100 today. This is repeated in the neighbouring Uganda, across in West Africa in Nigeria and Ghana. I will come to the challenges associated with this rapid growth later, but to respond to Barr, it is presumable that there has to be a threshold at which the "free" is bad for access starts, and presumably, this is also associated with the macro-economic context. Yet the discourse on higher education finance has often ignored to discuss a threshold on the context-specific dimensions of cost-sharing.

In sub-Saharan Africa context with less than adequate level of participation in higher education (averaging about $6 \%$ ) even though universities have opened quite rapidly in recent years in some countries, it cannot be said that the free is "bad" for access threshold, assuming this threshold exists, has been reached. It is therefore necessary to debate and reflect on the role of the private market vis-a-vis that of the state and to not promote a government attitude that is in support of the notion that "free is bad for access". This can be detrimental to equity and meaningful development of higher education. The market has a role, but in situations of low participation, access has to be the role of the government, in ensuring that higher education is accessible and does not cheat students and their families by producing graduates who have only marginal aptitudes beyond those who have completed good basic education. There are examples of bad access as a result of both state and market principles of funding higher education (see e.g. Heyneman et al. 2008, discussion on corruption in higher education in Eastern Europe). Furthermore, it would be pointless to expand access, even under the market system which produces graduates who are unable to think critically, communicate effectively, and unlikely to be numerate to the level expected of a university graduates. Such systems cheat students and their families. A country that has under $5 \%$ cohort enrolment and is not as large as China or India, may have to seriously question the idea that free university education is bad for access, but at the same time it has to be careful not to expand university that produces graduates that its economic system is not ready to utilise or lack skills that are associated with university graduates. Universities are poor at producing the so-called entrepreneurs in large scale, so if this is the model that is required, then considerations could be directed to apprenticeships.

The second key argument advanced by Barr is "elitism", and he rightly points out that elitism should have no place in higher education. The thrust of this argument is that "social background per se should not influence access to the best universities" (Barr p. 266). 
However, the rejoinder that Barr has is that intellectual elitism should not be an issue of concern. The challenge in sub-Saharan Africa is how to separate the two when intellectual elitism is intertwined with socio-economic class of children way below at primary level, and the meritocratic method of selection into universities reinforces this.

In the end, these two tenets, moral argument and elitism, are complex in sub-Saharan Africa. The debate about how best to fund higher education may not be as simply transferrable from one context to another as Barr has suggested. This complexity has created some of the serious challenges with the funding models that were proposed by the World Bank and adopted by countries in sub-Saharan Africa under the demand management policies of the 1980s. In the next sections, I will discuss some of these funding models and highlight concerns with their implementation through several examples which I will mention.

\section{Models of funding}

\section{Fees-supported funding model and access}

Over the last decade, many more students have gained access to university in sub-Saharan Africa, more than quadrupling enrolment in some cases, and there has also been considerably greater diversity in the offerings of many higher education institutions in terms of courses and the types of universities available. As noted by UNESCO Institute of Statistics (UIS 2010, p. 1) "Enrolment in tertiary education grew faster in sub-Saharan Africa than any other region over the last four decades. While there were fewer than 200,000 tertiary students enrolled in the region in 1970, this number soared to over 4.5 million in 2008-a more than 20-fold increase". This rapid expansion is illustrated by Fig. 1. Categories now include traditional (older) universities, newer state universities, and a proliferation of private universities. These changes for some are welcome because they are associated with the introduction of fees and a move away from dominance of "free" university to the involvement of the market in higher education, whereas for others, they have commodified education and affected quality seriously.

Fees have come in the form of meeting the full economic cost or through what is referred to as cost-sharing whereby students meet the partial cost of their university education while the government pays for the rest. Initially, there were protests when tuition fees were first seriously introduced in the 1990s in countries such as Kenya, Ghana, Uganda, but today fees have somewhat become increasingly accepted as necessary for access and to redress underfunding amidst greater demand. The concern is that governments have more or less taken a back seat in so far as funding is concerned, expecting universities to find their own sources for effective funding, but this has meant that universities rely on student tuition fees at the expense of good student learning experience and research by academics who have to undertake heavy teaching generated by large classes. All public universities in East Africa, notably Kenya and Uganda, and in West Africa, notably Ghana, now run what is called "dual-track model" whereby a small number of students are enrolled on state funding and another group, usually twice or more the number on state funding, are enrolled to pay the full economic cost on their own. Universities have found a way to maximise the benefits from this because the infrastructure used by fully subsidised and full-fee-paying students is the same. In addition, they have contracted staff who have already been contracted to teach fully subsidised students, leading to a situation 
Tertiary gross enrolment ratios by region, 1970 to 2008

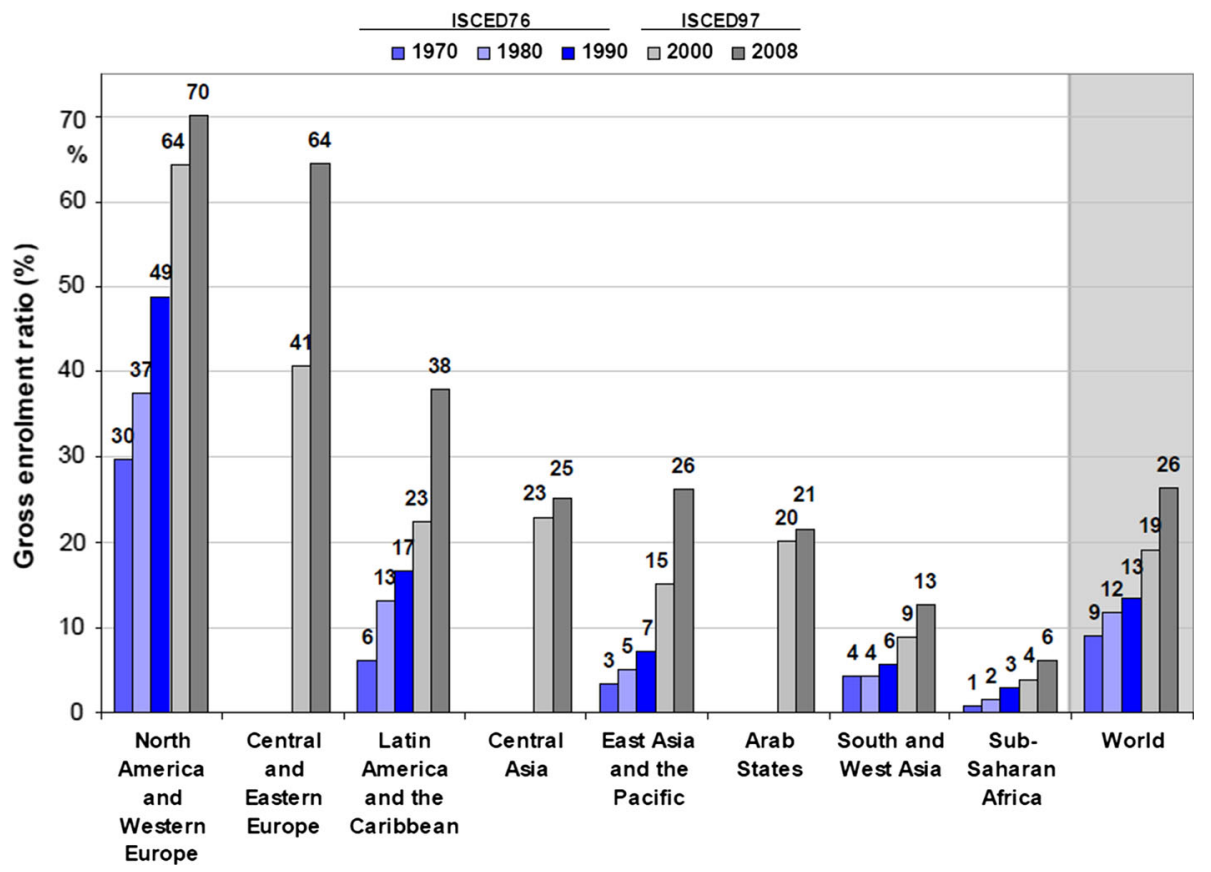

Fig. 1 What are the long-term trends for participation in tertiary education? Source reproduced from UIS 2010

of double-dipping in universities. By 1999, Makerere had perfected this by moving from a situation where none of its students paid any direct tuition fees to one whereby $70 \%$ paid fees (Court 1999). Today, full-fee-paying students at Makerere University in Uganda are in far greater number than those whose tuition fees is subsidised by the government. Nairobi University in Kenya and Kenyatta University also in Kenya followed suit in the footsteps of Makerere and similarly enrol many more students who are self-sponsored than those funded by the government. These universities such as Makerere, Nairobi, Kenyatta have become transformed for better or worse, depending on how one looks at fees, such that they are now "enterprises" with claims of flexible resources and reduced reliance on the state for their survival. The question is often whether true learning can occur with such large number of students. The perception is that quality has deteriorated and universities have over-done the "dual-track" funding model. Instead of complementing government resources, fees have in real terms increasingly displaced government funding, a valuable result that has also been observed by Carpentier (2012) in the UK. Teaching work load has been increased leaving little breadth for research. In these countries, such as Uganda and Kenya, there is no political debate that tuition is prohibitive. As a result of tuition-based expansion through the dual-track parallel model, universities are said to have invested heavily in infrastructure, some of which are not well planned and less clearly geared towards addressing immediate quality challenges, and salaries to staff who have to hop from one college campus to another to teach. Little is known about how this is leading to greater socio-economic homogenisation of universities and higher education, whereby 
those who access university are those able to pay for it, and it is possible the quality of higher education they are receiving is not completely what they deserve.

\section{Loans dependent model}

Loans are a feature of university funding all over the world (Ziderman 2002), although there are those who have argued that such loans add to student debt upon their graduation (see, e.g. Callender and Jackson 2008 for the case of England). Loans tend to have the following advantages: they increase access to higher education; they make the richer students to contribute to university budget; they increase the seriousness of students towards their studies and thus minimise or eliminate dropout; and they are considered a fair way of expanding higher education. However, whether loan is a feasible way of expanding access and maintaining quality in low-income countries is arguable. In countries such as the USA, loan is a way of life and students accept that, and most recently in the UK, it has grudgingly been accepted as the way to realise $50 \%$ participation rate. In these countries, students take loans and will pay it back. Their government are concerned with how to keep graduate unemployment low, and in the case of the UK, at what level of income should repayment start and after how long should outstanding balances be written off. These are big debate issues of serious political and economic considerations. The aim of such models as in UK is to promote equality of opportunity and equality of outcome such that someone who starts poor but ends up very rich pays more than someone who starts poor but ends up less rich. It also makes it possible for someone poor and someone rich to have equal access at the point of use. This according to Barr is fair to society and everyone (Barr 2004).

In Africa, student loans have been rushed without considering their complexity and context, and in the end, these loans have had several problems which have commonly been identified in the literature. They have narrowly calculated returns on investment(Colclough and Lewin 1993); a wanting credit market and the poor management of these loans (Arrow 1993); high non-repayment rate and a lack of effective system to track down on the defaulters, and in places where the default rate is so high, it is pointless to call it a loan (Tilak 1992). Other problems include high cost associated with the administration of these loans in the first place, in some instances as high as $20 \%$ of the overall loan amount; and there is less clarity and agreement on who should be the lender. Governments simply do not have enough resources to lend students, and banks are unwilling to agree to anything with uncertain governments that can change quickly and a culture of accountability that is less than adequate (Oketch 2003).

Presently, there are no clear debates about what kind of loan scheme is feasible in Africa as those that have existed have simply been tinkered with and the recovery is minimal. Income-contingent loans sound appropriate, but they would also require that there is serious debate about university graduate employment opportunities. It would be pointless to expand loan-fuelled demand for university education with graduates who in the end do not have employment opportunities. This will create a supply driven funding that is not matched with the demand for the degrees produced and a dilution of human capital. But eventually loans are essential, particularly if the idea of university expansion is well thought out and well designed to grow with the economic need and not simply as a response to popular demand and political statement. As Johnstone (1998) noted, loans defer the expected student financial contribution to their university education and thus ease the burden at the point of use. But loans that simply become grant because of the challenges which have been highlighted above will not expand access to those who, otherwise, will find it difficult to go to university. The key to a functional loan is to reasonably shift 
some cost of higher education to the student, and to achieve this, there has to be an effective recovery mechanism (Johnstone et al. 1998). As Johnstone (1998) points out, an effective loan scheme is one that on the balance of things promotes access at a cost to the government than would have otherwise been possible through a grant or "free" university system. If this is not feasible via loans, then the economic and moral arguments about loans become contested.

If taken that loans should work to promote access, how should they look like in the context in sub-Saharan Africa? Firstly, loans have to be reasonably affordable. It makes no sense for high interest and expensive loans that saddle beneficiaries with debts that they cannot possibly repay in contexts of low wages and low employment; it is about managing expectation given the economic context. This requires that the macro-economic environment is thoughtfully considered as part of the loan equation model. Secondly, loans may need to be portable which would mean that in the context of diversified offering of university education, admission to university is made flexible to suit the needs of the students. It is argued that such loans offer the freedom for poor students who meet university entry requirement to go to universities which are high cost or highly selective as they will not ex-ante be put off by unaffordable means to university, thus demotivating them to put in the extra effort required to meet the admission criteria for such selective institutions. Thirdly, loans should be sufficient to cover the full cost of university education including acceptable personal expenses such as room and board, clothing, etc. When loans are inadequate, they affect students learning and fail to serve their purpose (Oketch 2003). One of the good things associated with income-contingent loans is that it appeals to social justice because it has both the element of equal opportunity and fair sharing of repayment burden. It is not a one pair of shoes fits all model that is currently prevalent in some of the few loan schemes that exist in Africa. As Oketch (2003, p. 102) noted, "student loans can be a lifeline but a slippery one. The trick [is] to find a balance between providing subsidies to needy students, and making loan programmes financially sustainable". The same token applies to fees which have clearly shown that they can revitalise the higher education in some aspects.

\section{Expanding access and responding to demand}

The model of funding is crucial in the expansion of access and responding to demand for higher education in sub-Saharan Africa. However, "information" is equally as important, including raising awareness among those who otherwise do not see university as meant for them. Some of the ways by which the poor can be targeted include income-tested grants; giving money to universities to support scholarships for students from poor backgrounds; and incentives that promote aspiration for university education among the most underrepresented population groups. These will require clear legislation and policy debate. There is evidence that private financing can meet demand and support to a degree, selffunctioning universities. The fears that were common in the first wave of the introduction of "private funding" have now been overcome as there is now an acceptance that some reliance on private finance is essential. Some of the positive things that have occurred as a result of the dual-track model include competitive courses, reduced violent riots by students over trivial issues, and wasteful idle facilities which were common place when students were sent home on long holidays. Campuses in some countries no longer close because of the dual-track model. The students who pay the full cost do not want to overstay 
their years at university because this adds cost to their education (Oketch 2003). As Oketch notes, "in the past, [when university was considered "free"], this did not matter to many students.

To summarise, flexible tuition [fees] supported by income-contingent loans redistribute from today's richer population who lose a fraction of their tuition subsidies to enable greater numbers of less rich and poor students to gain a place at the university, who with income-contingent loans, do not have to pay the full cost if they do not secure reasonable employment. There is no known African country that clearly has this model, and the UK has been experimenting with it. To a larger extent, this is a great contract between a government and all sections of its population. On the one hand, the student is assured of a place without charges at the point of use, and on the other, a government must worry about the management of the economy and conducive political economy environment that can help generate employment for the graduates, who, in turn, repay their loans. This can be said to be a reasonable redistributive programme if implemented with equity and quality in mind and well. The setback is that loan schemes have not been implemented well in Africa and the macro-economic context has instead generated inefficiencies in higher education through graduate unemployment. In addition, fees can work, if managed properly such that they are not excessive and poorly invested on less important and less immediate priorities for addressing quality teaching and learning. We have seen this with the rapid expansion of the dual-track models. These dual-track models have enabled the government and universities, in some instances to literally kill two birds with one stone: expand access through evening programmes which do not affect the regular students, while also providing universities with resources to redress their dilapidated conditions and expand facilities. The problem now faced in several countries is that universities are over-doing it such that quality has become an issue of major concern.

Therefore, the question that should now be asked is what is the appropriate level of implementation of the dual-track programme? And should this be a government decision or should it be left to the higher education institutions (HEIs) and their management? The trend and practice thus far has left it to HEIs and their management to decide, but there is also now growing concern over quality and excessive expansion of these dual-track programmes which has called into question the judgement of HEIs and their managers. In some cases, such as in Kenya recently the government has stepped into discuss a framework that can regulate excessive and perverse incentives for dual-track programme expansion. An ideal scenario should be one whereby the market is left to function semiautonomously but with clear government regulatory framework which could include a cap on the level of expansion that is expected for each category of university, and heavy penalty for those HEIs which excessively expand and undermine the quality of university education.

\section{Discussion and conclusion}

There is resurgence of interest in research and understanding of the role of higher education in the development of the low-income countries (Oketch et al. 2014) and policy is focused on two main issues: promoting access and improving quality. Both are fundamental for development in SSA. As Oketch (2003, p. 91) noted, "the access objective is important both for its own sake and because Africa has the lowest enrolments in higher education compared to other regions of the world". The quality objective is vital in a world 
where knowledge has become increasingly important for economic growth. "Achieving both objectives is dependent on financial resources available to higher education" (Oketch 2003, p. 91). Several positive things that are associated with higher education such as producing competent civil servants are necessary for effective running of government responsibilities, individuals with the capacity to manage businesses, enterprise, and professional fields such as law and banking. Other benefits include traction for foreign direct investment, research and development, adaptation of new knowledge in context and so forth. Recent trends towards democratisation and the forging of national identity are often associated with higher education. All these are good reasons why any government might see it necessary to provide "free" higher education to its population. Similarly, these reasons have been used by those who advocate for publicly funded higher education, as they are conceived to convey the message of greater good of higher education to society. But these debates are relatively easy when the macro-economic environment is positive. When there is dismal economic performance, the competing demands for resources tend to shift the focus away from higher education.

In the 1980s and 1990s, the situation was so bad that most universities were simply dilapidated shells of what they once were; examples included Makerere University in Uganda. Recently, due to different funding models, things have improved. In universities such as Kenyatta University in Kenya, infrastructure has improved a lot though there are reports that it is still inadequate to meet fully the standards of quality learning. Lecture halls still overflow beyond levels considered conducive for meaningful effective learning in some cases. Today, however, the pessimistic picture of the African university once described by Coombe (1991) of complete dilapidation is no longer fully applicable nor is it a true depiction of the African university. Neave's "things fall apart" analogy in his description in his writing about higher education in Africa (Neave 2003) is also not applicable today in several cases. There is much hope and enthusiasm injected by the diversified funding models. There are still some challenges such as faculty who hustle for additional income by hoping from one campus to another to teach or running individually contracted consultancies rather cheaply outside the university, libraries are low in books and journals, but there is also now greater access through agreements such as HINERA network that allows African universities greater access to journal materials electronically or at highly subsidised costs and sometimes free access. Generally, physical facilities are improving at some of the key universities in Africa mainly because the idea of centrally planned university which led to their formation in the 1970s has given way to a diversified enterprise model whereby universities are no longer tied to price control, quantity control, and a bureaucratic quality control (see, e.g. Barr 2004 for the case of the UK). African universities have implemented new solutions which has reduced reliance on state funds.

There is evidence that private funding has revitalised higher education in sub-Saharan Africa and enabled universities to accommodate excess demand but as Oketch (2003, p. 104) points out the desirability of private funding and determining what constitutes an acceptable level remains a formidable issue that requires to be debated and addressed by African governments. At the same time, there is nothing wrong with elite model and provision so long as there are also other provisions of tertiary education that are not considered elite. Elite alongside non-elite would be viable. Serious consideration under a "free" university funding model has to be directed towards finding ways of supporting bright students from disadvantaged backgrounds. In addition, publicly financed model has to have a very clear way of linking higher education to employability of the graduates; otherwise, it is pointless to produce graduates who have nothing to do in the economy and who soon use their knowledge to create rent-seeking cartels. This has led to entrenched 
corruption in some countries. Rather than spread funding thinly to many institutions through rapid expansion, it is better to restrict funding to few institutions based on present needs but which produce productive graduates with multiplier effect in the labour market.

Furthermore, as growth occurs and the society becomes wealthy, there would be nothing wrong to consider greater private finance. As put by McMahon, "how far the trend toward privatization should go depends primarily on the extent to which higher education generates social benefits that are above and beyond private benefits to the student and his or her family. Sometimes this issue generates more heat than light. The position at one extreme is that higher education programs should be privatized and forced to cover their full costs, otherwise they will not be efficient. At the other extreme is the position that the market should have no role whatsoever, that the academy should be exempt" (McMahon 2009, pp. 11-12). These debates are ongoing in Africa as well. However, "for one thing, there are sources of market failure in higher education markets that cause fully privatised markets to be inefficient. For example, there is poor information about what the nonmarket private benefits really are and also about specifically what the public benefits are. Where there is poor information, private markets fail, and the result is economic inefficiency. In contrast, there is relatively good information about the contribution of a college education to earnings" (McMahon 2009, p. 13). For higher education to position itself towards playing meaningful role in sustainable development in Africa, there will need to be a balance on the extent to which the market model can be allowed to prevail. In the end, the state will have to play a key role in terms of both setting up functional regulatory frameworks to safeguard quality, and to support university access through greater funding in order to strengthen equality of opportunity and equality of outcome.

\section{Future research on cost-sharing}

Research into the mechanisms for financing of higher education in sub-Saharan Africa which can deliver expanded access, quality and equity will depend and largely draw on a framework of the macro-economic context, demographic shift, demand and supply, and the regulatory framework for delivering and managing sustainable quality higher education in the region. There is no doubt that there will be implications for theoretical analysis on the role of the market versus that of the state, issues around possible market failure, as well as issues around non-market benefits of higher education drawing particularly on the endogenous development theorising and the sustainable development aspirations vis-a vis cost-sharing. The evidence available indicates that there is room for some level of private funding which has been associated with expanded participation in some countries, but there has also been concern over the effect of this rapid expansion funded through entrepreneurial activities of the universities on quality. The renewed interest in higher education's role in the development of sub-Saharan Africa is welcome news, but a focus on understanding the connection between different funding models with quality and equity would be more immediate areas for both theorising and empirical research work on cost-sharing.

Only limited amount could be said about actual loans that are in operation now because there is limited research in this area, and progress in the understanding of the kinds of loan schemes that could work to expand access in Africa would require research attention. Probably, a more immediate research and equally as important is employability of university graduates, because this will shed some light on the external efficiency of these universities, which has implications for cost-sharing policies. 
Open Access This article is distributed under the terms of the Creative Commons Attribution 4.0 International License (http://creativecommons.org/licenses/by/4.0/), which permits unrestricted use, distribution, and reproduction in any medium, provided you give appropriate credit to the original author(s) and the source, provide a link to the Creative Commons license, and indicate if changes were made.

\section{References}

Arrow, K. J. (1993). Excellence and equity in higher education. Education Economics, 1, 5-12.

Barr, N. (2004). Higher education funding. Oxford Review of Economic Policy, 2(2), 264-283.

Barro, R. (2000). The contribution of education to economic growth. In: OECD, Quebec conference proceedings, Quebec, Canada.

Becker, G. S. (1993). Human capital: A theoretical and empirical analysis with special reference to education (3rd ed.). Chicago: Chicago University Press.

Callender, C., \& Jackson, J. (2008). Does the fear of debt constrain choice of university and subject of study? Studies in Higher Education, 33(4), 405-429.

Carpentier, V. (2012). Public-private substitution in higher education: Has cost-sharing gone too far? Higher Education Quarterly, 66(4), 363-390.

Colclough, C., \& Lewin, K. (1993). Educating all children: Strategies for primary schooling in the south. Oxford: Clarendon.

Coombe, T. (1991). A consultation on higher education in Africa: A report to the ford foundation and the Rockefeller Foundation. London: University of London, Institute of Education.

Court, D. (1999). Financing higher education in Africa: Makerere, the quiet revolution. Washington, DC: World Bank.

Dearden, L., Fitzsimons, E., \& Wyness, G. (2014). Money for nothing: Estimating the impact of student aid on participation in higher education. Economics of Education Review, 43, 66-78.

Fernandez, R., \& Rogerson, R. (1995). On the political economy of education subsidies. Review of Economic Studies, 62, 249262.

Greenaway, D., \& Haynes, M. (2003). Funding higher education in the UK: The role of fees and loans. The Economics Journal, 113, F150-F166.

Hanushek, E., \& Woessmann, L. (2008). The role of cognitive skills in economic development. Journal of Economic Literature, 46, 607-668.

Heyneman, S. P., Anderson, K. H., \& Nuraliyeva, N. (2008). The Cost of Corruption in Higher Education. Comparative Education Review, 52(1), 1-25.

Johnstone, B. (1998). Financing higher education: Who should pay and other issues. In P. G. Altbach, R. O. Berdahl, \& P. J. Gumport (Eds.), American higher education in the 21st century: Social and economic challenges. Baltimore: John Hopkins University Press.

Johnstone, B., Arora, A., \& Experton, W. (1998). The financing and management of higher education: A status report on world reforms. Washington, DC: World Bank.

Keller, K. R. I. (2006). Investment in primary, secondary, and higher education and the effects on economic growth. Contemporary Economic Policy, 24(1), 18-34.

Lucas, R. E. (1988). On the mechanics of economic development. Journal of Monetary Economics, 22(1), 3-42.

Mankiw, G. N., Romer, D., \& Weil, D. N. (1992). A contribution to the empirics of economic growth. The Quarterly Journal of Economics, 107(2), 407-437.

McCowan, T. (2012). Is there a universal right to higher education? British Journal of Educational Studies, 60(2), 111-128.

McMahon, W. W. (2009). Higher education. Greater Good: The Johns Hopkins University Press, Baltimore.

McMahon, W. W., \& Oketch, M. (2013). Education's effects on individual life chances and development: An overview. British Journal of Educational Studies, 61(1), 79-107.

Neave, G. (2003). Africa: Things fall apart? Higher Education Policy, 16, 255-258.

Oketch, M. (2003). Affording the unaffordable: Cost-sharing in higher education in sub-Saharan Africa. Peabody Journal of Education, 78(3), 88-106.

Oketch, M. (2006). Determinants of human capital formation and economic growth of African Countries. Economics of Education Review, 25(5), 554-564.

Oketch, M., McCowan, T., \& Schendel, R. (2014). The impact of tertiary education on development: A rigorous literature review. London: DFID.

Psacharopoulos, G. (1994). Returns to investment in education: A global update. World Development, 22(9), 1325-1343. 
Psacharopoulos, G., \& Patrinos, H. A. (2004). Returns to investment in education: A further update. Education Economics, 12(2), 111-134.

Rosen, H. S. (1995). Public finance (4th ed.). Homewood, IL: Irwin.

Rozada, M., \& Menendez, A. (2002). Public university in Argentina: Subsidizing the rich? Economics of Education Review, 21, 341-351.

Teal, F. (2011). 'Higher education and economic development in Africa: A review of channels and interactions. Journal of African Economies, 20(AERC Supplement 3), iii 50-iii 79.

Tilak, J. B. (1992). Student loans in financing higher education in India. Higher Education, 23, 389-404.

UIS. (2010). Trends in tertiary education: Sub-Saharan Africa. Quebec: UNESCO, UIS.

UIS. (2014). http://www.uis.unesco.org/DataCentre/Pages/country-profile $\cdot$ aspx ?regioncode $=40500 \&$ code $=$ GBR. Accessed on 2nd November 2015.

Woodhall, M. (2001). Financing higher education. The potential contribution of fees and student loans (Vol. 12). Boston College, International Higher Education.

Ziderman, A. (2002). Financing student loans in Thailand: Revolving fund or open ended commitment? Economics of Education Review, 21, 367-380. 